\title{
Polishing of synthetic electroplating wastewater in microcosm upflow constructed wetlands: Effect of operating conditions
}

Adam SOCHACKI ${ }^{1,2 *}$, Joanna SURMACZ-GÓRSKA ${ }^{1}$, Olivier FAURE$^{2}$, Bernard GUY ${ }^{2}$

${ }^{1}$ Environmental Biotechnology Department, Faculty of Power and Environmental Engineering, Silesian University of Technology, ul. Akademicka 2, PL-44 100 Gliwice, Poland

${ }^{2}$ Ecole Nationale Supérieure des Mines, GéoSciences \& Environnement Département, CNRS:UMR 5600, EVS; 158, cours Fauriel, F-42023 Saint-Etienne Cedex 2, France

*Corresponding author. Tel. +48 32 2371169, Fax. +48 322372946

E-mail addresses: adam.sochacki@polsl.pl, joanna.s.gorska@polsl.pl, ofaure@emse.fr, bguy@emse.fr

Abstract This paper addresses the issue of polishing electroplating wastewater in subsurface vertical flow constructed wetland. Electroplating wastewater treatment or polishing in constructed wetlands (CWs) was studied to a very limited degree. Four types of microcosm upflow constructed wetlands were selected for the experiment based on type of bed media and the presence or absence of vegetation (Phragmites australis). The main objective of the system design was to promote metals removal by precipitation as sulfides mediated by sulfate reducing bacteria. The experimental system consisted of eight PVC columns (diameter $20 \mathrm{~cm}$ ) filled up to. $63.5 \mathrm{~cm}$ with either gravel or gravel-peat mixture and was operated for one year, polishing synthetic electroplating wastewater. The wastewater used in this study contained metals $(\mathrm{Cu}, \mathrm{Ni}, \mathrm{Pb}$ and $\mathrm{Zn})$, cyanides and sulfates, which typically occur in electroplating wastewater. During the experiment the effect of the following factors was studied: presence of vegetation, hydraulic loading, wastewater strength, type of bed media, and addition of lactates as external carbon source for the columns with gravel. The results showed that the uplow columns can efficiently remove metals (with the exception of $\mathrm{Pb}$ ) and cyanides. It was observed that the removal efficiency of $\mathrm{Cu}, \mathrm{Ni}$ and $\mathrm{Zn}$ increases with increasing influent concentration of metals and increasing hydraulic loading rate. The role of plants and bed media was minor. The addition of lactates to the feed of the columns with gravel was found to improve the reduction of metals concentration in the passing wastewater.

Keywords electroplating wastewater, metals, cyanides, constructed wetlands, upflow, sulfates

\section{Abbreviations}




$\begin{array}{ll}\text { COD } & \text { chemical oxygen demand } \\ \text { CW } & \text { constructed wetland } \\ \text { DW } & \text { dry weight } \\ \text { ECS } & \text { external carbon source } \\ \text { HLR } & \text { hydraulic loading rate } \\ \text { HRT } & \text { hydraulic retention time } \\ \text { MAD } & \text { median absolute deviation } \\ \text { SRB } & \text { sulfate-reducing bacteria } \\ \text { UF } & \text { upflow } \\ \text { UF-GP } & \text { vegetated upflow column with gravel } \\ \text { UF-GU } & \text { unvegetated upflow column with gravel } \\ \text { UF-PP } & \text { vegetated upflow column with peat } \\ \text { UF-PU } & \text { unvegetated upflow column with peat }\end{array}$

\section{$1 \quad$ Introduction}

Electroplating is a process of applying metal coating to an object to enhance its protective properties and alter its appearance, or both [1]. High concentrations of toxic pollutants in the electroplating effluents (metals and cyanides often in hundreds of $\mathrm{mg} / \mathrm{L}$ [1]) preclude direct application of biological methods for their treatment. Thus, constructed wetlands (CWs) are not an alternative to conventional physical-chemical methods of electroplating wastewater treatment. The term 'polishing' is understood as a treatment of wastewater, pretreated by conventional methods, to the level that allows discharge into sewer or the environment. Thus, the polishing process would be employed to reduce residual amounts of metals and cyanides, which are invariably present in the electroplating wastewater. It is noteworthy that conventional primary and secondary unit processes at municipal wastewater treatment plants are not fully adequate for efficient removal of heavy metals and cyanides of electroplating origin, and the biological processes may be inhibited by these contaminants if the biomass was not previously adapted [2-4]. Moreover, treatment of wastewater containing metals by activated sludge impairs the quality of the excess sludge precluding its agricultural application [5]. Thus, even the polishing of wastewater discharged into municipal sewer should be important from the environmental perspective. The application of CWs for the treatment of electroplating wastewater was reported scarcely in the literature. Ranieri and Young [6] studied the removal of $\mathrm{Ni}$ and $\mathrm{Cr}$ (and other contaminants) from municipal wastewater containing about $20 \%$ of electroplating and textile wastewater. This study consisted in monitoring of a full-scale $\mathrm{CW}$ with horizontal subsurface flow. The treatment of electroplating effluents was also investigated in the system with water hyacinth in Asia [7, 8]. Vymazal and Kröpfelová [9] referred to the work of Shroff [10] that was dealing to some extent with the treatment of electroplating wastewater. The important feature of metals is that 
they can only be removed from wastewater but cannot be destroyed. This allows assumption that metals are accumulated in wetland substrate or biota [6]. The removal of metals in subsurface CWs is dominated by four mechanisms: adsorption, filtration and sedimentation, association with metal oxides and hydroxides, and precipitation as sulfides. The extent of these processes depends on the type of the $\mathrm{CWs}, \mathrm{pH}$, redox potential, influent composition, the dominant plant species and microbial activity [11]. Since, in general, metal sulfides are less soluble than their carbonate or hydroxide counterparts, this process allows achieving more complete precipitation and stability over a broader $\mathrm{pH}$ range [12]. Some of the metals which react with sulfides to form highly insoluble metal sulfides are: $\mathrm{Cu}, \mathrm{Fe}, \mathrm{Ni}, \mathrm{Pb}$, and $\mathrm{Zn}$. These metals are often present in electroplating wastewater [13]. The key requirements for sulfate-reducing systems are: anaerobic conditions (oxidation-reduction potential below -100 $\mathrm{mV}$ ), electron donors (simple organic compounds), microbial groups capable of utilizing inorganic sulfur compounds as electron acceptors; inorganic sulfur compounds (as electron acceptors) [14-16]. The major factor limiting the application of microbial sulfate reduction to the removal of metals from carbon deficient industrial wastewaters (such as electroplating wastewater) in CWs is the availability of carbon and energy sources to drive the process. In order to stimulate sulfate-reducing bacteria (SRB) in the case of carbon-deficient effluents, a proper carbon source should be provided to enhance their growth and to cause other bacteria to remove the oxygen from the environment [11]. Unlike for natural wetlands, sulfates are not limiting substance in CWs treating industrial wastewater, as sulfuric acid is often used to adjust $\mathrm{pH}$ of wastewater [11]. The conditions favorable for SRB may occur in various types of wetland systems, but the upflow (UF) CWs appear viable solution. They are characterized by the fact that their bed is constantly saturated and permanently flooded over the surface. UF CWs are, in fact, mostly applied when anaerobic treatment processes should be promoted, such as bacterial sulfate reduction [17]. Importantly, also cyanides can be degraded under anaerobic conditions in various biotic and abiotic processes [18].

The goals of the experiment were to study the feasibility of polishing electroplating wastewater and to study the effect of hydraulic loading, vegetation, type of bed media, wastewater strength, and addition of external carbon source.

\section{$2 \quad$ Materials and methods}

\subsection{Microcosm constructed wetlands}


The experimental system consisted of eight PVC columns (height, $H=80 \mathrm{~cm}$, diameter, $d=$ $20 \mathrm{~cm}$ ) filled up to $63.5 \mathrm{~cm}$ with either mineral or mixed organic-mineral media. The active bed area $(A)$ corresponding to these dimensions was $0.0314 \mathrm{~m}^{2}$, the bed volume $(V)$ was $20 \mathrm{~L}$. The columns were operated in a UF saturated mode with a $6.5-\mathrm{cm}$ layer of water above the bed media preventing air from penetrating into the substrate. Thus, water depth (h) in the system was invariably $70 \mathrm{~cm}$ and the corresponding nominal wetland volume $\left(V_{\text {nom }}\right)$ was $22 \mathrm{~L}$. These columns were fed from the bottom by peristaltic pump Masterflex ${ }^{\circledR} L / S^{\circledR} 7523-80$ using PharMed ${ }^{\circledR}$ BPT tubing $(2.79 \mathrm{~mm})$ and the outlet was situated $70 \mathrm{~cm}$ above the bottom. The schematic of column used in the experiment is shown in Fig. 1.

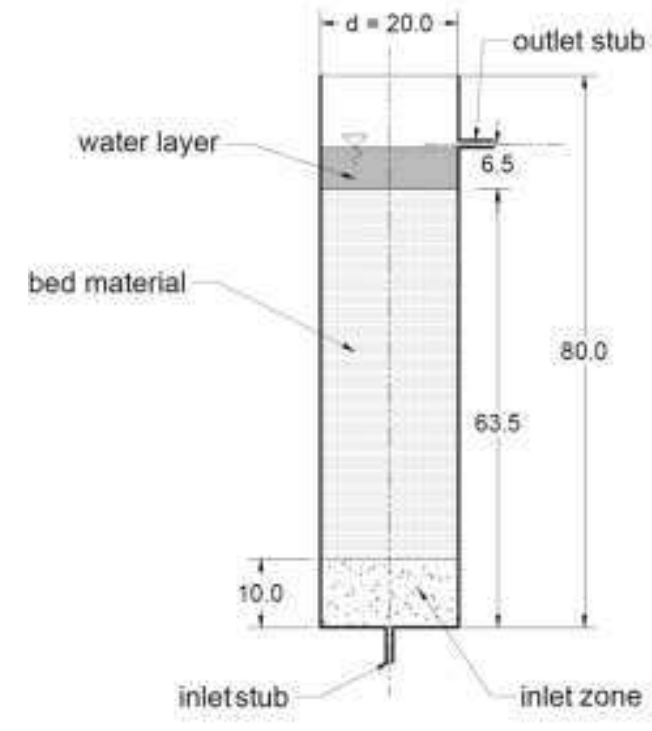

(a)

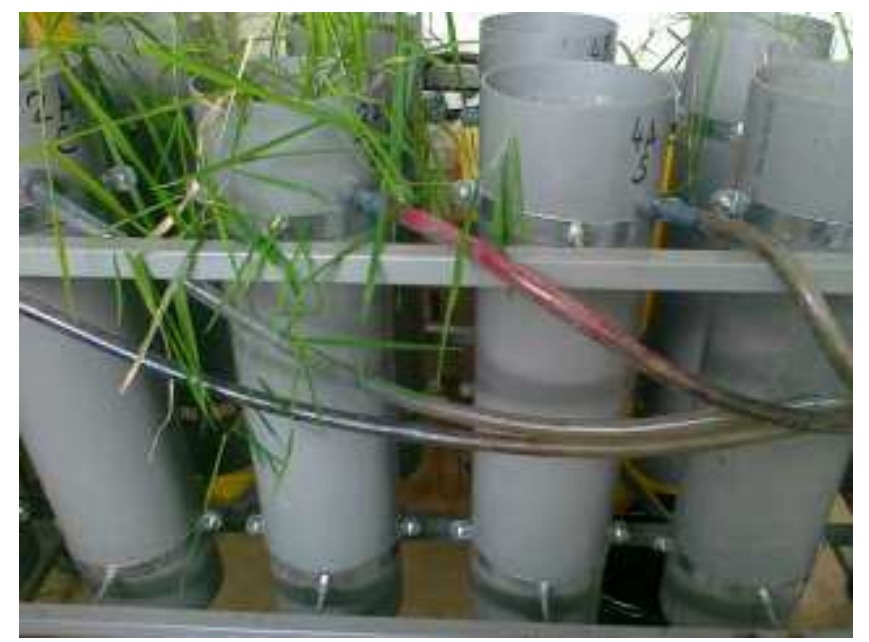

(b)

Figure 1 (a) Cross section of a column used in the experiment (all dimensions in $\mathrm{cm}$; in scale), and (b) photo of the experimental system

The main objective of the system design was to promote metals $(\mathrm{Cu}, \mathrm{Ni}, \mathrm{Pb}, \mathrm{Zn})$ removal by precipitation as sulfides mediated by SRB, which, in general, are obligate anaerobes. Anaerobic conditions in the columns were promoted by their construction and operation mode. The columns were filled with quartz gravel $(3-8 \mathrm{~mm})$ or equivolume gravel-peat mixture (hereafter referred to as 'peat'). The inlet zone at the bottom of the columns with peat contained 10-cm layer of the gravel (as shown in Fig. 1). The pH value of the peat was 3.54.5; organic matter content $89.9 \%$ of DW, and water-holding capacity $746 \mathrm{~mL} / \mathrm{L}$. The bed media were inoculated with SRB using anaerobic sludge (mesophilic anaerobic digestion) with initial 14-day batch of wastewater to all the columns prior to the start-up of the experiment. Selected columns were planted with rhizomes of Phragmites australis (Cav.) Trin. ex Steud and Phalaris arundinacea L. Four types of UF-CWs were selected for the 
experiment based on type of bed media and the presence or absence of vegetation. Eight columns were used in this study, since each type of column was duplicated. The following types of columns were used:

- columns filled with peat and planted (UF-PP),

- columns filled with peat and unplanted (UF-PU),

- columns filled with gravel and planted (UF-GP),

- $\quad$ and columns filled with gravel and unplanted (UF-GU).

The experimental system was situated in laboratory conditions in Gliwice, Poland. It was in operation from January, 2012 to January, 2013, which is 53 weeks. The feed of the system was prepared by dissolving salts of metals and sulfates in tap water in a $250-\mathrm{L}$ container. The salts used were $\mathrm{Pb}\left(\mathrm{NO}_{3}\right)_{2}, \mathrm{NiSO}_{4} \cdot 6 \mathrm{H}_{2} \mathrm{O}, \mathrm{ZnCl}_{2}, \mathrm{CuSO}_{4} \cdot 5 \mathrm{H}_{2} \mathrm{O}, \mathrm{Na}_{2} \mathrm{SO}_{4}$. The system was fed with low-strength and high-strength wastewater. The former was fed from January, 2012 to April, 2012, and the latter from May, 2012 to January, 2013. The concentration of sulfates was equal in the both influents at $500 \mathrm{mg} / \mathrm{L}$ (resulting from dissolution $\mathrm{Na}_{2} \mathrm{SO}_{4}$ ), and the $\mathrm{Pb}$ concentration was equal at $1 \mathrm{mg} / \mathrm{L}$ throughout the experiment. The final concentration of sulfates was higher (up to $860 \mathrm{mg} / \mathrm{L}$ ) in the feed because of sulfates in the tap water used. The concentration of $\mathrm{Cu}, \mathrm{Ni}$ and $\mathrm{Zn}$ was raised from $1 \mathrm{mg} / \mathrm{L}$ in the low-strength feed to $5 \mathrm{mg} / \mathrm{L}$ in the high-strength feed. In week 33 the inflow rate $\left(Q_{\text {in }}\right)$ to the columns was decreased from 3.25 to $2.00 \mathrm{~mL} / \mathrm{min}$. In week 44 of the experiment lactates were started to be added to the influent fed to the columns with gravel (UF-GP, UF-GU). Lactates were added to the feed as $80 \%$ lactic acid and the dosage was calculated based on the assumption that a target ratio $\mathrm{COD} / \mathrm{SO}_{4}^{2-}$ is 0.3 . This value was based on the study of Song et al. [19] where it was found to be the optimum ratio. The concentration of sulfates used for calculation was $800 \mathrm{mg} / \mathrm{L}$ (real concentration was close to this value) and the corresponding COD of lactates was $240 \mathrm{mg}$ $\mathrm{O}_{2} / \mathrm{L}$. In week 48 cyanide was started to be added to all the types of columns. Cyanide was added as $\mathrm{KCN}$ in a dosage equal to $2.0 \mathrm{mg} / \mathrm{L}$ of total cyanide. All the operation periods are given in Tab. 1. 
Table 1 Operation chart for the experimental system (grey shading indicates relevant periods)

\begin{tabular}{|c|c|c|c|c|c|c|}
\hline \multirow[t]{5}{*}{ Operation mode } & \multirow[t]{4}{*}{ Columns } & \multicolumn{5}{|c|}{ Weeks of operation } \\
\hline & & $1-17$ & $18-32$ & $33-43$ & $44-47$ & $48-53$ \\
\hline & & \multicolumn{5}{|c|}{ Month and year } \\
\hline & & Jan 12 & May 12 & Aug 12 & Nov12 & Dec 12 \\
\hline & \multicolumn{5}{|c|}{ Influent quantity } & \\
\hline $\mathrm{Q}_{\text {in }}{ }^{1}=3.25 \mathrm{~mL} / \mathrm{min}$ & All & & & & & \\
\hline $\mathrm{Q}_{\text {in }}=2.00 \mathrm{~mL} / \mathrm{min}$ & All & & & & & \\
\hline \multicolumn{7}{|c|}{ Influent quality } \\
\hline Low-strength feed & All & & & & & \\
\hline High-strength feed & All & & & & & \\
\hline \multirow[t]{2}{*}{ Addition of lactate } & UF-PP/UF-PU & & & & & \\
\hline & UF-GP/UF-GU & & & & & \\
\hline Addition of cyanide & All & & & & & \\
\hline
\end{tabular}

\subsection{Wastewater analysis}

Effluent was sampled from the columns by either syringe from the outlet zones of the columns or collected to plastic bottles connected by plastic hose to the outflow stubs of the columns. Influent samples were taken by syringe or by immersion of sample vials, depending on water level. Metals $(\mathrm{Cu}, \mathrm{Fe}, \mathrm{Mn}, \mathrm{Ni}, \mathrm{Pb}, \mathrm{Zn})$ were analyzed with flame atomic adsorption spectrometry (FAAS; Varian Spectra AA 800) after acidifying filtered samples with 65\% $\mathrm{HNO}_{3}$ to $\mathrm{pH}<2$. The detection limits for metal analysis by FAAS were 0.0015, 0.0040, $0.0020,0.0010 \mathrm{mg} / \mathrm{L}$ for $\mathrm{Cu}, \mathrm{Ni}, \mathrm{Pb}, \mathrm{Zn}$, respectively. Standard deviation was calculated for each measurement series and was less than $5 \%$ for each metal considered. The analysis was performed using duplicate samples. Readily liberated cyanides were determined using Merck Cuvette test 1.09701.0001. In this method (for samples decomposed by digestion) cyanide ions react with a chlorinating agent to form cyanogen chloride, which in turn reacts with 1,3dimethylbarbituric acid to form a violet dye (pyridine-free König reaction). This dye was determined photometrically using Merck Spectroquant NOVA 400 spectrophotometer. Standard deviation of the method was $\pm 0.0039 \mathrm{mg} / \mathrm{L}$, coefficient of the variation of the method was $\pm 1.5 \%$, and confidence interval was $\pm 0.010 \mathrm{mg} / \mathrm{L}$. Chemical oxygen demand (COD) of wastewater was determined using standard method of reflux digestion and titration ISO 6060:1989 [20]. Sulfate was determined using Merck Cuvette test 1.14791.0001. In this method (for samples decomposed by digestion) sulfate ions react with barium iodate, liberating iodate ions in the process. These oxidize tannin to a brown-red compound that was determined photometrically using Merck Spectroquant NOVA 400 spectrophotometer. 
Standard deviation of the method was $\pm 4.8 \mathrm{mg} / \mathrm{L}$, coefficient of the variation of the method was $\pm 2.6 \%$, and confidence interval was $\pm 9 \mathrm{mg} / \mathrm{L}$.

\subsection{Statistical analysis}

Most of the subsets of the performance data had non-normal distribution, therefore nonparametric statistical test were used to compare these subsets. Median and the median absolute deviation (MAD) were used as descriptors of the central tendency and dispersion of data distributions for non-normally distributed data. The Shapiro-Wilk W test was employed to test for normality of the data. Dependent groups were analyzed using the Wilcoxon matched pair test and independent groups were analyzed using the Mann-Whitney $U$ test. Differences were considered statistically significant if $p<0.05$. Statistical testing was performed using the STATISTICA 10 software [21].

\section{Results and discussion}

\subsection{Overall treatment efficiency for metals}

The experimental system was used to treat synthetic electroplating wastewater in four types of columns, of which some were left unplanted. The unplanted columns were used as a reference for the planted systems and were not considered CWs in this paper. The median values of the removal efficiency for metals in all the columns during the whole experiment (weeks 1-53) are presented in Fig. 2. 


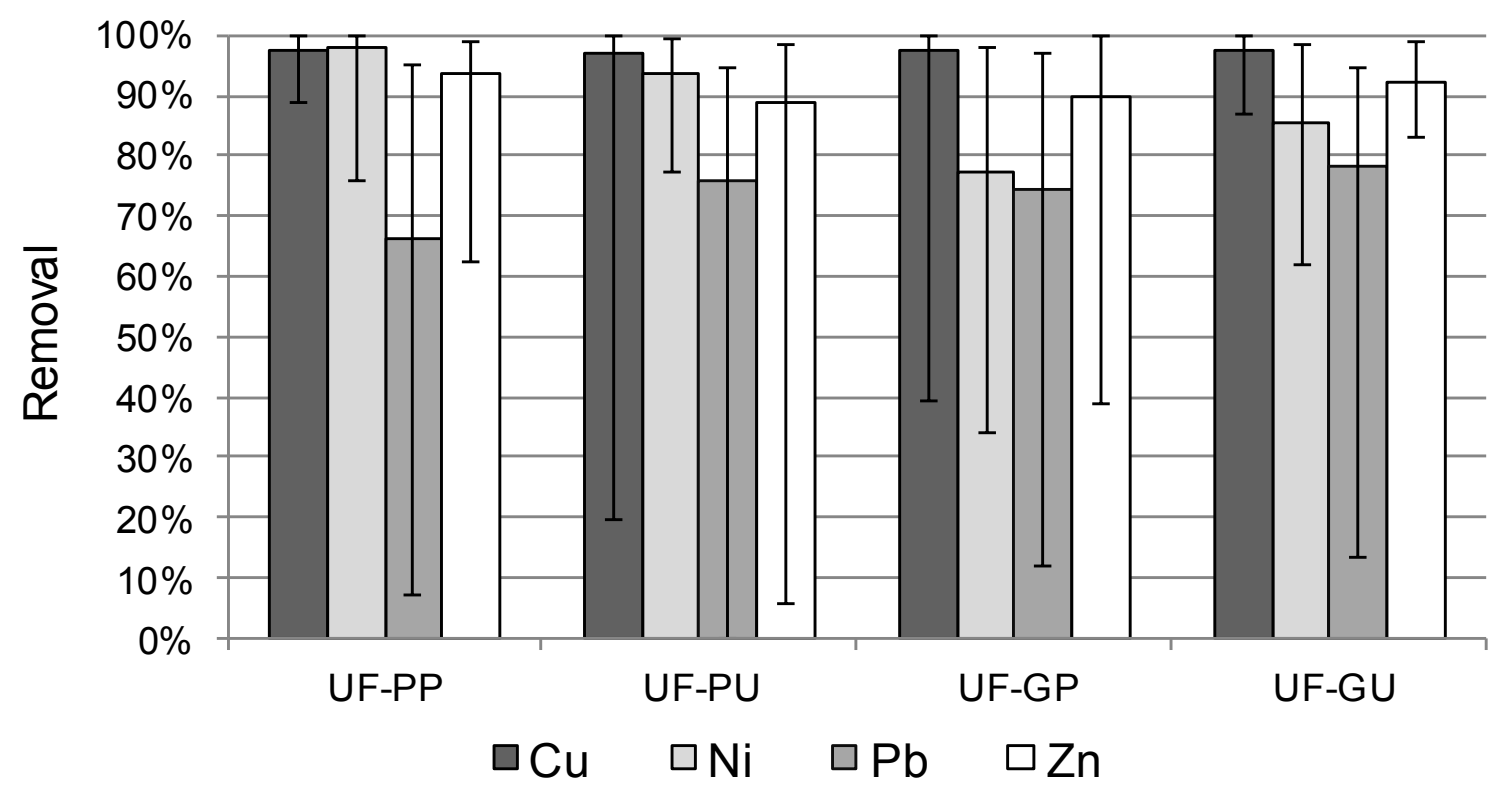

Figure 2 Median removal efficiencies (and max. and min. values indicated by whiskers; in \%) in the columns of the experimental system during the experiment $(\mathrm{n}=$ 24-26), weeks 1-53

The results presented in Fig. 2 do not allow assuming general order of removal efficiency for metals in all the columns. The decreasing removal order in the UF-PP CWs was $\mathrm{Ni}>\mathrm{Cu}>\mathrm{Zn}$ $>\mathrm{Pb}$ and in the UF-GP CWs it was $\mathrm{Cu}>\mathrm{Zn}>\mathrm{Ni}>\mathrm{Pb}$. The lowest removal efficiency was observed for $\mathrm{Pb}$ in all the types of the investigated columns. In general, the UF-PP columns offered better removal efficiency than the UF-GP columns. The removal of $\mathrm{Cu}, \mathrm{Ni}$ and $\mathrm{Zn}$ was above $90 \%$ (97.4\%; 98.1\%; 93.4\%, respectively) in the UF-PP columns. Only the removal of $\mathrm{Pb}$ was low in this type of $\mathrm{CW}$ and was $66.0 \%$. In comparison the removal of $\mathrm{Cu}$ in the UF-GP columns (97.6\%) was almost equal to the removal in the UF-PP columns. The removal of $\mathrm{Ni}$ and $\mathrm{Zn}$ was lower in the UF-GP columns than in the UF-PP columns and was $77.2 \%$ and $89.2 \%$, respectively. The CWs filled with organic media (UF-PP) reduced the Ni concentration with higher efficiency than observed for this metal in the UF-GP columns, probably due to increased binding affinity of peat for $\mathrm{Ni}$. As it was mentioned above the lowest removal in the UF-GP columns was observed for $\mathrm{Pb}$ and was $74.2 \%$.

Noteworthy, the superiority of the UF-PP columns in removal of metals based on the median data was not observed in all the periods of the experiment. For this reasson, the efficiency of metals and sulfates removal in different operational periods were shown in Sections 3.2 and 3.4 . 


\subsection{Metals removal in the course of the experiment}

The median data as shown in Fig. 2 facilitate comparison of several systems but does not allow visualizing the time course of the process. Figure 3 presents the influent and effluent concentrations of $\mathrm{Cu}, \mathrm{Ni}, \mathrm{Pb}$ and $\mathrm{Zn}$, respectively, on time scale. These graphs allow for observation of time-dependent changes due to internal factors and external factors, which are changes introduced intentionally (or sometimes occurring stochastically) during the experiment. The internal factors that govern the treatment in the studied CWs can be sorption capacity for metals, stimulation or inhibition of microorganisms, clogging, etc. The external factors can be controlled and monitored (e.g. flow rate, feed composition), monitored but uncontrolled (e.g. temperature) and uncontrolled and non-monitored. The internal behavior of the system can be to some extent caused by the external factors controlled during the experiment. For example, the activity of SRB can be increased providing more advantageous conditions for their growth. The trendlines in Fig. 3 represent two-period moving averages.

\section{Data for UF-PP columns}

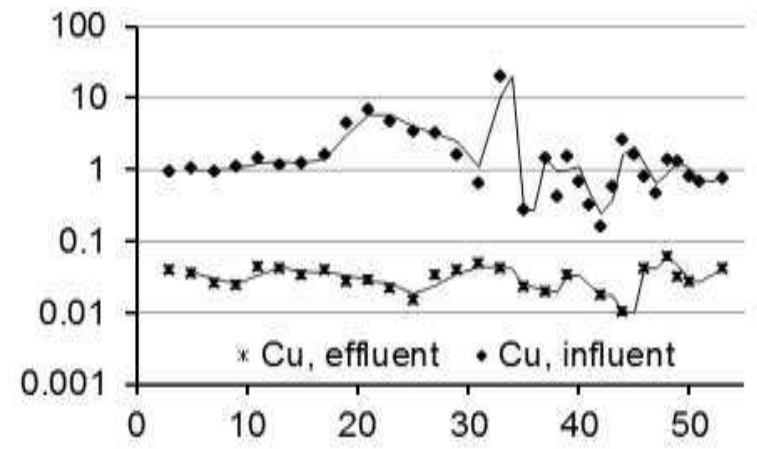

(a)

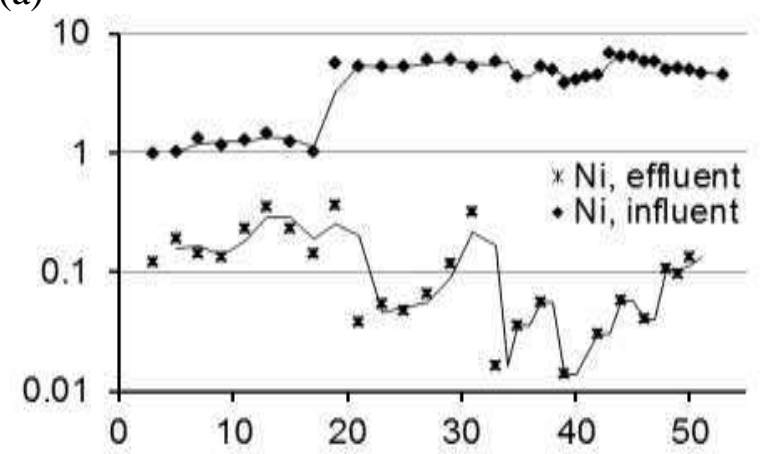

(b)

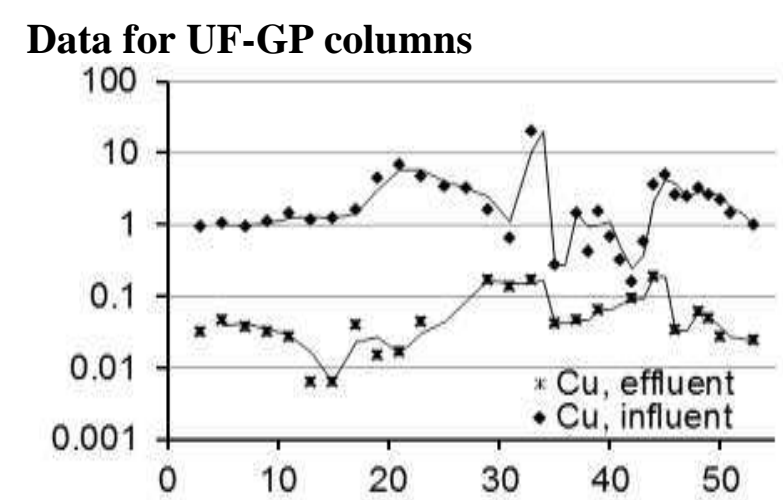

(e)

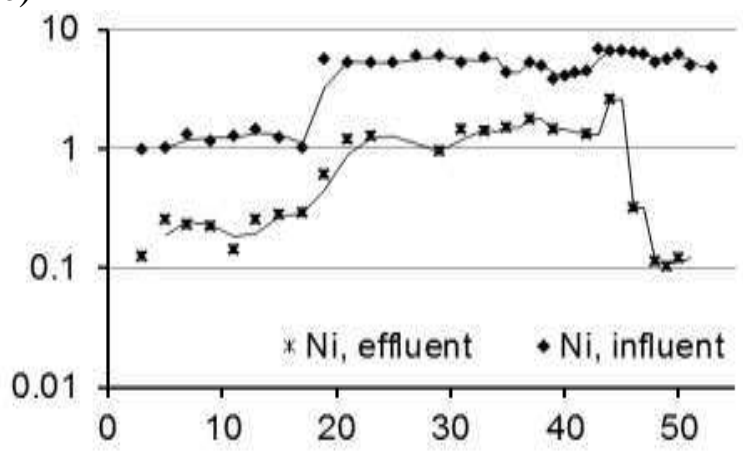

(f) 

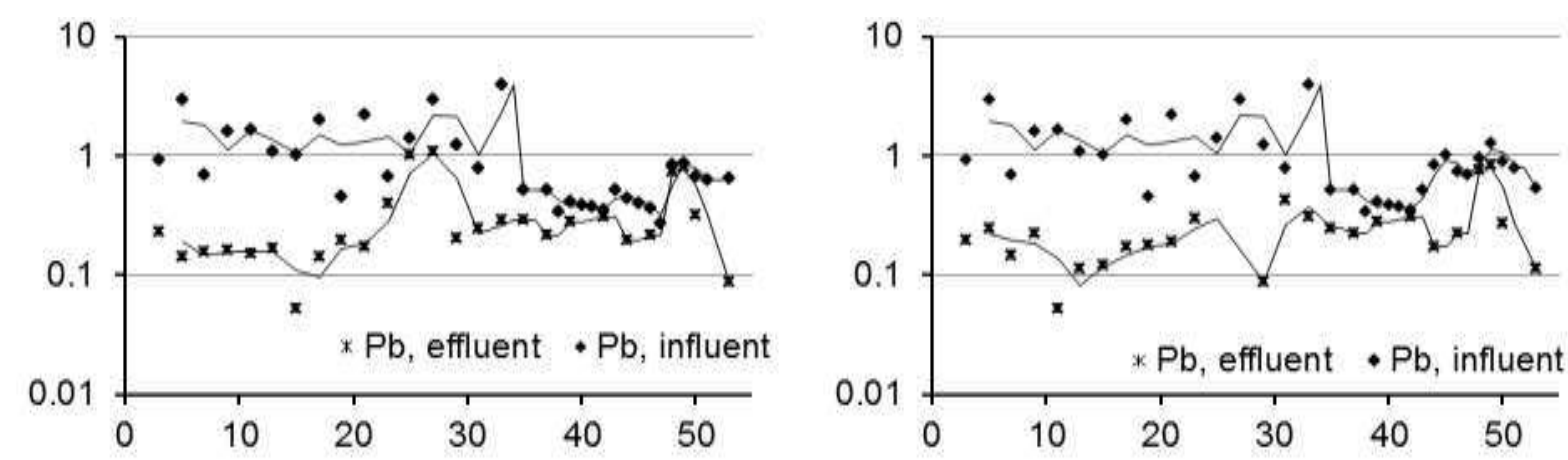

(c)

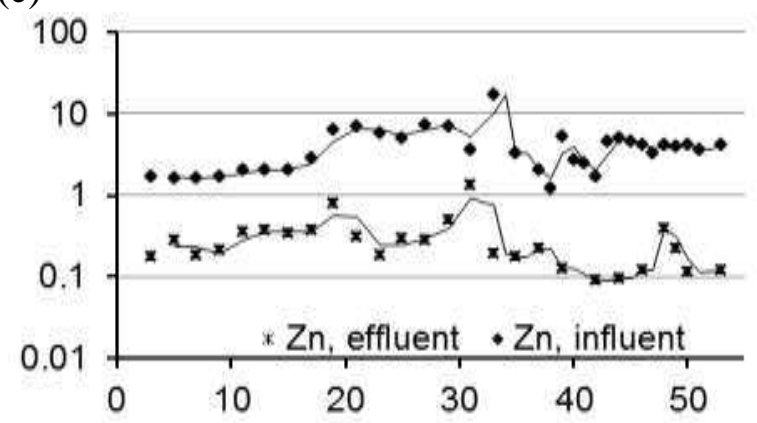

(g)

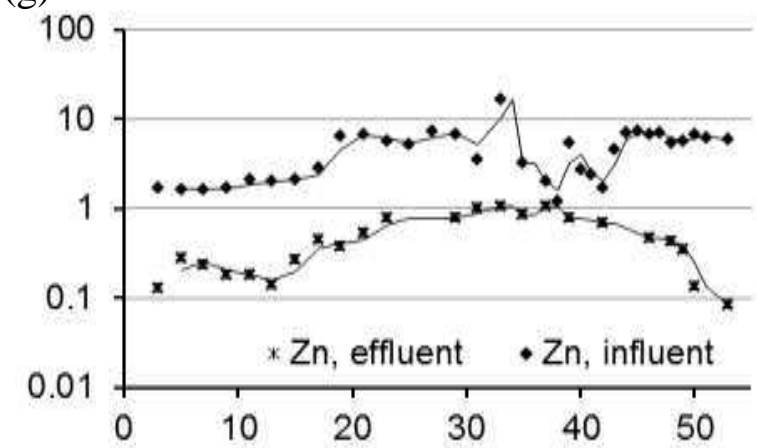

(d)

(h)

Figure $3 \mathrm{Cu}, \mathrm{Ni}, \mathrm{Pb}$ and $\mathrm{Zn}$ concentrations in the influent and effluent of the UF-PP (ad), UF-GP (e-h) columns as a function of time; concentration, (mg/L) on ordinate, time (weeks) on abscissa; weeks $1-53 ; \mathrm{n}=33$, influent; $\mathrm{n}=23-26$, effluent

It can be observed in Fig. 3 that the relation between effluent concentration and operation mode is not clearly visible for $\mathrm{Cu}, \mathrm{Pb}$ and $\mathrm{Zn}$. The exception is the data for Ni concentration in the effluent of both types of planted columns. It can be observed in Fig. $3 b$ that the effluent $\mathrm{Ni}$ concentration decreased below $0.1 \mathrm{mg} / \mathrm{L}$ when high-strength feed was applied in the UFPP columns. In the UF-GP columns (Fig. 3f), however, the influent and effluent conetrations of $\mathrm{Ni}$ were proportional. The effect of various operation mode was presented and discussed in further sections. The concentration of $\mathrm{Cu}$ in the effluent of the UF-PP and UF-GP columns was most data points in the range of 0.01 to $0.1 \mathrm{mg} / \mathrm{L}$. For $\mathrm{Ni}, \mathrm{Pb}$ and $\mathrm{Zn}$ effluent concetration most of data points were in the range of 0.1 to $1 \mathrm{mg} / \mathrm{L}$ with the exception of $\mathrm{Ni}$ in the UF-PP columns. It was also observed that the effluent concentration of $\mathrm{Cu}, \mathrm{Ni}$ and $\mathrm{Pb}$ were stable or increasing towards the end of the experiment. In contrast, it was observed that the effluent concetration of $\mathrm{Zn}$ was slightly decreasing. It should be noted that the decrease of effluent metal concetration in the UF-GP columns (after week 44) can be attributed to the addition of lactates serving as external carbon source. It was observed that the addition of lactates caused the most significant decrease of metal effluent concentration in the case of $\mathrm{Ni}$. The effect of cyanide addition to the feed (week 48) is not evident. 


\subsection{Treatment efficiency of CWs for cyanides}

Cyanides are an inherent compound of the electroplating wastewater. In the experiment system cyanides were added to the high-strength feed starting from week 48 . The influent and effluent cyanide concentration and the removal efficiencies are presented in Tab. 2. The removal efficiencies given in Tab. 2 were calculated based on median influent and effluent concentrations. The influent concentration of cyanides were different for columns with mineral and organic media, as these two types of columns were fed with wastewater with lactate and without lactate, respectively, from separate tanks

Table 2 The influent and effluent concentrations (median \pm MAD) of readily liberated cyanides an corresponding removal efficiencies in all the types of columns (weeks $48-53 ; \mathrm{n}=5-8$ )

\begin{tabular}{llllll}
\hline & \multicolumn{5}{c}{ Column type } \\
\cline { 3 - 6 } & & UF-PP & UF-PU & UF-GP & UF-GU \\
\hline Influent & Median & $1.043^{1}$ & $1.043^{1}$ & $1.280^{2}$ & $1.280^{2}$ \\
mg/L & MAD & 0.534 & 0.534 & 0.851 & 0.851 \\
Effluent & Median & 0.056 & 0.085 & 0.085 & 0.080 \\
mg/L & MAD & 0.043 & 0.065 & 0.044 & 0.028 \\
Removal & & & & & \\
\% & & $94.7 \%$ & $91.9 \%$ & $93.4 \%$ & $93.8 \%$ \\
\hline${ }^{1}$ for the feed without lactates, ${ }^{2}$ for the feed with lactates
\end{tabular}

The results presented in Tab. 2 indicate that the removal of cyanides was higher than $91 \%$ in all the UF columns. All the effluent concentrations were statistically different from the corresponding influent concentrations. The differences in removal between the columns are not pronounced and the effect of bed media and vegetation cannot be clearly demonstrated.

\subsection{Effect of operational conditions on the treatment efficiency}

The design of the experimental system was intended to allow for comparison of the effect of various operational conditions and configuration of the columns. The overall averaged data for the whole experiment or the data presented on the time scale are not suitable for analyzing the results in this regard. In this section the effect of various factors is assessed based on the data paired according to the effect of interest. This is, each pair comprises two data sets, one set where the factor with a potential effect on the treatment efficiency occurred and the other set, in which this factor was absent. The analyzed data were divided into relevant periods to 
enable meaningful conclusions drawn from the comparison. The significance of the difference between two relevant data sets was assessed statistically.

\subsubsection{Effect of wastewater strength}

The experimental system was fed with either low- or high-strength wastewater, which was intended to simulate the treated electroplating effluent and pretreated electroplating effluent, respectively. The low-strength influent was fed in the beginning of the experiment (weeks 1-17) and the high-strength was fed in the remaining period (weeks 18-53). The operational conditions of the experimental system were changed after week 33 (see Tab. 1), therefore the effect of wastewater strength can be assed properly only for the periods of weeks 1-17 for low-strength wastewater, and week 18-32 for high strength wastewater. The results from these periods were compared to assess whether the strength of the influent affected the treatment efficiency. It should be noted that these two influents were not fed into the columns in parallel, so the apparent difference between the treatment efficiencies in these periods cannot be solely attributed to the effect of the wastewater strength but could also be caused by the system's maturation. The comparison of the removal efficiency of the UF columns between the periods when the system was fed with low-strength wastewater (weeks 1-17) and highstrength wastewater (weeks 18-32) is presented in Tab. 3.

Table 3 Influent quality and treatment efficiencies (median \pm MAD) in the UF-PP and UF-GP columns fed with low- (Low) and high-strength influent (High), (weeks: 1-17 for low-strength influent, $\mathrm{n}=8 ; 18-32$ for high-strength influent, $\mathrm{n}=8$ )

\begin{tabular}{llllll}
\hline Metal & Parameter & UF-PP & \multicolumn{3}{l}{ UF-GP } \\
\cline { 3 - 6 } & & Low & High & Low & High \\
\hline $\mathbf{C u}$ & Influent [mg/L] & $1.14 \pm 0.15$ & $3.93 \pm 1.60$ & $1.14 \pm 0.15$ & $3.93 \pm 1.60$ \\
& Removal [\%] & $\mathbf{9 7 . 1} \pm \mathbf{0 . 5}$ & $\mathbf{9 9 . 5} \pm \mathbf{0 . 2}$ & $97.4 \pm 1.1$ & $99.2 \pm 0.6$ \\
$\mathbf{N i}$ & Influent [mg/L] & $1.19 \pm 0.14$ & $5.42 \pm 0.34$ & $1.19 \pm 0.14$ & $5.42 \pm 0.34$ \\
& Removal [\%] & $\mathbf{8 3 . 9} \pm \mathbf{3 . 3}$ & $\mathbf{9 9 . 0} \pm \mathbf{0 . 6}$ & $81.5 \pm 5.1$ & $76.0 \pm 2.9$ \\
$\mathbf{P b}$ & Influent [mg/L] & $1.33 \pm 0.37$ & $1.34 \pm 0.77$ & $1.33 \pm 0.37$ & $1.34 \pm 0.77$ \\
& Removal [\%] & $\mathbf{9 0 . 4} \pm \mathbf{4 . 7}$ & $\mathbf{6 6 . 0} \pm \mathbf{2 1 . 6}$ & $88.9 \pm 2.9$ & $58.4 \pm 14.3$ \\
$\mathbf{Z n}$ & Influent [mg/L] & $1.87 \pm 0.21$ & $\mathbf{6 . 5 9} \pm 1.22$ & $1.87 \pm 0.21$ & $6.59 \pm 1.22$ \\
& Removal [\%] & $\mathbf{8 5 . 2} \pm \mathbf{2 . 5}$ & $\mathbf{9 4 . 9} \pm \mathbf{2 . 1}$ & $88.5 \pm 3.3$ & $92.3 \pm 5.9$ \\
\hline \multicolumn{2}{l}{ Statistically }
\end{tabular}

Based on the results presented in Tab. 3 it can be seen that all the differences between the removal efficiencies in the given periods for the UF-PP columns were statistically significant, in contrast to the to the UF-GP columns where none of the differences were of statistical significance. In the high-strength-influent period the operation of the UF-GP was unstable for two weeks because of tubing clogging and puncture, which could cause that outlying data 
points appeared in the data set for this period. It was, observed however, that the type of influent affected the operation of the UF columns in a similar manner. The removal of $\mathrm{Cu}$ was cca. $2 \%$ higher, in both types of columns, when the high-strength influent was used. Also, the removal of $\mathrm{Ni}$ was more efficient, by cca. $16 \%$, when the high-strength influent was fed to the UF-PP columns. It was the only exception to the similarity between the UF columns, when the Ni removal was lower by $5.5 \%$ during the period when the high-strength influent was fed to the UF-GP columns. It was probably owing to saturation of the gravel, which has lower sorption capacity than peat. The same observation as for $\mathrm{Cu}$ and $\mathrm{Ni}$ (only in the UF-PP columns) was observed for $\mathrm{Zn}$, which was removed to a higher extent in both types of the planted UF columns when these columns were fed with the high-strength influent. The efficiency of the Zn removal increased by cca. $10 \%$ and $4 \%$ for the UF-PP and UF-GP CWs, respectively. In contrary to the above findings (with the exception of the $\mathrm{Ni}$ removal in the UF-GP CWs), the Pb removal efficiency was markedly lower, by cca. $30 \%$ and $24 \%$, in the UF-PP and UF-GP CWs, respectively, when the high-strength wastewater was fed into these $\mathrm{CWs}$. However, in this period influent concentrations of only $\mathrm{Cu}, \mathrm{Ni}$ and $\mathrm{Zn}$ were increased from 1 to $5 \mathrm{mg} / \mathrm{L}$, but $\mathrm{Pb}$ concentration remained unadjusted at $1 \mathrm{mg} / \mathrm{L}$. This may suggest that the $\mathrm{Pb}$ removal was hindered by the increased concentration of the other metals.

\subsubsection{Effect of vegetation}

Plants are an inherent feature of CWs [22]. The significance of their effect on the removal of metals depends on many factors. Only a minor fraction of metals is removed by emergent hydrophytes in the subsurface-flow CWs [23]. The effect of plants on the removal of metals in the experimental system is presented in Tab. 4 where the data for the planted and unplanted UF columns are compared.

Table 4 The comparison between the treatment efficiencies (median \pm MAD, \%) in the planted and unplanted UF columns, (weeks 3-42; $\mathrm{n}=18-21$ )

\begin{tabular}{lllll}
\hline \multirow{2}{*}{ Metal } & \multicolumn{2}{l}{ UF with peat } & \multicolumn{2}{l}{ UF with gravel } \\
\cline { 2 - 5 } & $\begin{array}{l}\text { Planted } \\
\text { (UF-PP) }\end{array}$ & $\begin{array}{l}\text { Unplanted } \\
\text { (UF-PU) }\end{array}$ & $\begin{array}{l}\text { Planted } \\
\text { (UF-GP) }\end{array}$ & $\begin{array}{l}\text { Unplanted } \\
\text { (UF-GU) }\end{array}$ \\
\hline $\mathbf{C u}$ & $\mathbf{9 7 . 5} \pm \mathbf{1 . 5}$ & $\mathbf{9 6 . 5} \pm \mathbf{2 . 4}$ & $\mathbf{9 7 . 0} \pm \mathbf{2 . 2}$ & $\mathbf{9 7 . 5} \pm \mathbf{1 . 7}$ \\
$\mathbf{N i}$ & $\mathbf{9 6 . 0} \pm \mathbf{3 . 5}$ & $\mathbf{8 8 . 8} \pm \mathbf{4 . 7}$ & $\mathbf{7 6 . 0} \pm \mathbf{5 . 7}$ & $\mathbf{8 4 . 3} \pm \mathbf{2 . 6}$ \\
$\mathbf{P b}$ & $76.1 \pm 6.7$ & $80.1 \pm 11.0$ & $78.8 \pm 15.4$ & $80.8 \pm 11.5$ \\
$\mathbf{Z n}$ & $\mathbf{8 9 . 1} \pm \mathbf{5 . 7}$ & $\mathbf{8 7 . 5} \pm \mathbf{4 . 3}$ & $\mathbf{8 6 . 4} \pm \mathbf{5 . 9}$ & $\mathbf{9 2 . 7} \pm \mathbf{3 . 3}$ \\
\hline Statistically significant differences are shown in bold &
\end{tabular}

Statistically significant differences are shown in bold 
The differences between the data sets for the planted and unplanted counterpart columns were statistically significant for all the metals, except $\mathrm{Pb}$. The differences between the removal of $\mathrm{Cu}$ in the planted and unplanted UF columns filled with either gravel or peat are less or equal $1 \%$. The results for $\mathrm{Ni}$ are somewhat contradictory, as the presence of plants enhanced the treatment efficiency in the UF-PP columns by cca. $7.2 \%$, but it attenuated the removal of $\mathrm{Ni}$ in the UF-GP CWs by about $8 \%$. The same observation is valid for the removal of $\mathrm{Zn}$, which was higher (by only 1.6\%) in the UF-PP CWs than in the unplanted counterpart (UF-PU CWs), but was lower, by about $6 \%$, in the UF-GP than in the unplanted counterpart (UF-GU $\mathrm{CWs}$ ). The removal of $\mathrm{Pb}$ was higher in the unplanted UF columns, both in these filled with gravel or peat, and differed by $4 \%$ and $2 \%$, respectively. The number of stems per column was less than 10, thus probably, the below-ground biomass was insufficient as a substrate for biofilm and as a means of oxygen transfer into the bed media. Thus, neither biotic nor abiotic processes occurring in the planted columns were not affected significantly by the plants. The differences observed between the removal efficiencies in the planted and unplanted columns were probably due to the fact that the plants modified the hydraulic permeability of the upper part of the columns, thus affecting the removal.

\subsubsection{Effect of hydraulic loading rate}

The hydraulic loading rate (HLR) is an operational parameter that can be used to control the efficiency of the treatment in CWs. The complexity of the processes occurring in CWs for the removal of metals and cyanides causes that it is difficult to assume any value of the hydraulic retention time (HRT) in the beginning of the experiment as the optimum one. For this reason, two values of the hydraulic loading rate were studied: 0.15 and $0.09 \mathrm{~m} / \mathrm{d}$, which corresponded to the HRT values of $1.6-2.1 \mathrm{~d}$, and $2.7-3.4 \mathrm{~d}$, respectively. The comparison of the effect of HLR on the removal efficiency of metals is given in Tab. 5. The influent quality was not modified in the period, for which the data are given.

Table 5 Comparison of metal removal efficiency (median \pm MAD, \%) depending on the hydraulic loading in the UF columns

\begin{tabular}{lllll}
\hline Metal & \multicolumn{3}{l}{ UF-PP $^{1}$} & \multicolumn{3}{c}{ UF-GP $^{2}$} \\
\cline { 2 - 5 } & $\mathbf{0 . 1 5} \mathbf{~ m} / \mathbf{d}$ & $\mathbf{0 . 0 9} \mathbf{~ m} / \mathbf{d}$ & $\mathbf{0 . 1 5} \mathbf{~ m} / \mathbf{d}$ & $\mathbf{0 . 0 9} \mathbf{~ m} / \mathbf{d}$ \\
\hline $\mathbf{C u}$ & $99.6 \pm 0.2$ & $95.4 \pm 3.6$ & $99.1 \pm 0.7$ & $94.9 \pm 6.1$ \\
$\mathbf{N i}$ & $99.0 \pm 0.3$ & $99.2 \pm 0.1$ & $75.5 \pm 2.0$ & $66.1 \pm 4.2$ \\
$\mathbf{P b}$ & $\mathbf{6 9 . 1} \pm \mathbf{3 8 . 3}$ & $\mathbf{3 9 . 7} \pm \mathbf{1 6 . 1}$ & $55.5 \pm 24.7$ & $52.0 \pm 21.2$ \\
$\mathbf{Z n}$ & $95.6 \pm 1.4$ & $94.8 \pm 2.9$ & $89.3 \pm 7.5$ & $74.0 \pm 11.2$ \\
\hline${ }^{1}$ weeks $21-32(0.15 \mathrm{~m} / \mathrm{d} ; \mathrm{n}=7)$, weeks $33-47(0.09 \mathrm{~m} / \mathrm{d}, \mathrm{n}=7)$ \\
${ }^{2}$ weeks $21-32(0.15 \mathrm{~m} / \mathrm{d} ; \mathrm{n}=7)$, weeks $33-43(0.09 \mathrm{~m} / \mathrm{d}, \mathrm{n}=5)$
\end{tabular}


The results given in Tab. 5 indicate that the treatment efficiency was lower for the lower values $(0.09 \mathrm{~m} / \mathrm{d})$ of the HLR in both UF-PP and UF-GP columns. Only the removal of Ni in the UF-PP columns at both HLRs was virtually equal and the removal efficiency of $\mathrm{Cu}$ was higher for the lower HLR in the UF-GP columns. Most of the differences were not statistically significant with the exception of $\mathrm{Pb}$ in the UF-PP columns. The above findings suggest that the higher HLR is more advisable value rather than the lower one, however, two remarks should be made. Firstly, the decreased efficiency corresponding to the lower HLR can result from the chronology of the experiment. For example, the progressive saturation of the adsorption sites on the bed media could elucidate the decreased efficiency. In fact, it was observed that the effect of HLR was more pronounced in the columns with gravel (UF-GP) especially for $\mathrm{Ni}$ and $\mathrm{Zn}$, because gravel has much lower binding affinity for metals than peat. Secondly, only two values of the HLR were investigated, therefore no meaningful general conclusions can be drawn for a wider range of the values for this parameter. Similar findings were, however, presented in [24]. It was shown in this article that the removal of $\mathrm{Ni}$ and $\mathrm{Cr}$ was highest at lower hydraulic retention time $(24 \mathrm{~h})$ decreased markedly at HRT of $48 \mathrm{~h}$ for $\mathrm{Ni}$, and slightly for $\mathrm{Cr}$. The authors did not explain the causative factor. The other authors found that hydraulic loading rate had no effect on metal removal efficiency in subsurface-flow CWs [25] or that increased HLR enhanced the removal of metals in sulfate-reducing lab-scale reactors packed with a mixture of organic and inorganic materials [26], in pilot-scale horizontal flow CWs [27], and in vertical flow microcosm CWs [28].

\subsubsection{Effect of substrate type (internal carbon source)}

The CWs have the ability to reduce metal concentrations in the wastewater passing through. The removal of metals can occur under either oxic or anoxic conditions. In the experiment reported in this paper the removal processes were investigated under anoxic conditions. It was expected that the predominant removal process would be the precipitation of metals with biogenic sulfides. The generation of sulfides is mediated by SRB, which need organic carbon as an electron donor. The experimental system was designed to provide organic carbon as an internal source in the bed media, which was peat. Not all of the columns contained organic substrate so that the comparison of the effect of the internal carbon source would be possible. The data shown in Tab. 6 represent the treatment efficiency in weeks $33-43$, this is, before the addition of external carbon source to the wastewater in gravel- and peat-filled columns. 
Table 6 The comparison between the treatment efficiencies (median \pm MAD, \%) in the planted columns filled with gravel (UF-GP) or peat (UF-PP), (weeks 33-43; n $=4-5)$

\begin{tabular}{lll}
\hline \multirow{2}{*}{ Metal } & \multicolumn{2}{l}{ UF columns } \\
\cline { 2 - 3 } & UF-PP & UF-GP \\
\hline $\mathbf{C u}$ & $\mathbf{9 7 . 9} \pm \mathbf{4 . 1}$ & $\mathbf{9 7 . 0} \pm \mathbf{2 . 2}$ \\
$\mathbf{N i}$ & $\mathbf{9 9 . 3} \pm \mathbf{0 . 1}$ & $\mathbf{6 6 . 5} \pm \mathbf{4 . 2}$ \\
$\mathbf{P b}$ & $45.0 \pm 14.0$ & $52.0 \pm 21.2$ \\
$\mathbf{Z n}$ & $\mathbf{9 4 . 7} \pm \mathbf{2 . 9}$ & $\mathbf{7 4 . 0} \pm \mathbf{1 1 . 2}$ \\
$\mathbf{S O}_{4}^{2-}$ & $8.9 \pm 5.2$ & $-24.1 \pm 6.1$ \\
\hline
\end{tabular}

Statistically significant differences are shown in bold

The effect of substrate type in the planted UF columns was statistically significant for the removal of $\mathrm{Cu}, \mathrm{Ni}$ and $\mathrm{Pb}$ which was invariably in the columns with gravel (UF-GP). The removal efficiencies were not statistically different for $\mathrm{Pb}$, but interestingly the removal was higher (by 7.0\%) in the UF-GP columns. The removal of $\mathrm{Cu}$ was almost the same in both types of the discussed columns (only $0.7 \%$ higher in the columns with peat). Interestingly Scholz et al. [29] also found that internal carbon source does not enhance the removal of $\mathrm{Pb}$ and $\mathrm{Zn}$ in vertical-flow microcosm CWs, however, under aerobic conditions. The removal efficiencies were much higher in the columns with peat, this is, by $32.8 \%$ for $\mathrm{Ni}$, and $20.7 \%$ for $\mathrm{Zn}$. This suggests that peat affects the removal of $\mathrm{Ni}$ and $\mathrm{Zn}$. The effect of peat can be probably related to adsorption processes and the stimulation of SRB activity. The second hypothesis can be corroborated by the comparison of sulfates removal in the UF-PP and UFGP columns. The removal of sulfates was low, however, positive in the columns with peat, whereas sulfates were released from the columns with gravel. Neculita et al. [30] emphasized that solid organic sources do not significantly promote the activity of SRB unless used as a mixture of various carbon sources.

\subsubsection{Effect of the external carbon source addition}

The treatment of wastewater containing metals in anaerobic CWs is often based on the assumption that precipitation of metals with biogenic sulfides would be the predominant removal process. As it was already mentioned in this paper (Section1) the activity of the SRB depends on the availability of simple organic compounds, amongst other things. The source of these compounds may origin from the inside or the outside of the system. The former solution was applied when the experimental system was constructed by adding organic media to the bed media as peat. The latter source of organic carbon in the form of lactate was started to be added to the influent of the columns with mineral media (gravel) in week 44. 
The main goal of adding the external carbon source to the influent was to enhance the removal of metals. The comparison of the metal removal efficiencies in the columns treating the influent with and without the external carbon source is given in Tab. 7 for weeks $44-53$ of the experiment.

Table 7 Comparison between metal removal efficiencies (median \pm MAD, \%) in columns treating wastewater with external carbon source (ECS) and without external carbon source (No ECS) external carbon source (weeks 44-53, n = $5-8)$

\begin{tabular}{lll}
\hline \multirow{2}{*}{ Substance } & \multicolumn{2}{l}{ UF columns } \\
\cline { 2 - 3 } & UF-PP & UF-GP \\
\hline & No ECS & ECS \\
$\mathbf{C u}$ & $96.0 \pm 1.3$ & $98.1 \pm 0.6$ \\
$\mathbf{N i}$ & $98.1 \pm 0.8$ & $97.8 \pm 0.3$ \\
$\mathbf{P b}$ & $\mathbf{4 6 . 2} \pm \mathbf{3 2 . 6}$ & $\mathbf{6 9 . 6} \pm \mathbf{9 . 8}$ \\
$\mathbf{Z n}$ & $97.1 \pm 0.6$ & $93.5 \pm 3.0$ \\
$\mathbf{S O}_{4}^{2-}$ & $10.7 \pm 3.5$ & $4.0 \pm 21.9$ \\
\hline
\end{tabular}

Statistically significant differences are shown in bold

The results given in Tab. 7 suggest that the addition of the external carbons source may allow treatment with comparable metal removal efficiency. It can be seen in Tab. 7 that statistically significant difference between the removal efficiencies was only for $\mathrm{Pb}$, which was removed about $20 \%$ more efficiently in the UF-GP columns, than in the peat columns (UF-PP). The removal of sulfates is higher in the columns with peat, but the removal is low in all the types of columns presented in Tab. 7.

The data presented in Tab. 7 are of particular interest when the design decisions are to be made, but they furnish no information if the treatment efficiency was improved by the addition of the external carbon source. This information can be obtained, for example, by comparing the data in Tab. 6 and Tab. 7. More direct comparison of the treatment efficiency before and after the addition of the external carbon source is presented in Tab. 8 for weeks 4553 , this is with one-week lag relative to the moment when lactates were started to be added to the influent, and for weeks 33-44 when lactates were not added.

Table 8 Comparison between metal removal efficiencies (Median \pm MAD, \%) before (before ECS) (weeks 33-43, $\mathrm{n}=4-5$ ) and after addition of external carbon source (after ECS) to the feed of the UF-GP columns (weeks 45-53, n $=4-7$ )

\begin{tabular}{lll}
\hline Substance & UF-GP & \\
\cline { 2 - 3 } & Before ECS & After ECS \\
\hline $\mathrm{Cu}$ & $94.9 \pm 6.1$ & $98.2 \pm 0.5$
\end{tabular}




\begin{tabular}{lll}
$\mathrm{Ni}$ & $\mathbf{6 6 . 1} \pm \mathbf{4 . 2}$ & $\mathbf{9 7 . 9} \pm \mathbf{0 . 2}$ \\
$\mathrm{Pb}$ & $52.0 \pm 21.2$ & $69.5 \pm 21.5$ \\
$\mathrm{Zn}$ & $\mathbf{7 4 . 0} \pm \mathbf{1 1 . 2}$ & $\mathbf{9 3 . 9} \pm \mathbf{1 . 8}$ \\
$\mathrm{SO}_{\mathbf{4}}^{2-}$ & $\mathbf{- 2 4 . 1} \pm \mathbf{6 . 1}$ & $\mathbf{4 . 0} \pm \mathbf{2 1 . 9}$ \\
\hline
\end{tabular}

Statistically significant differences are shown in bold

The addition of the external carbon source improved the removal efficiency of metals and sulfates as shown in Tab. 8. The statistically significant differences were observed for $\mathrm{Cu}, \mathrm{Ni}$, $\mathrm{Zn}$ and sulfates in the UF-GP columns. The most pronounced improvement of the treatment efficiency was obtained for $\mathrm{Ni}$ (by about 32\%) in the UF-GP columns. Only the removal efficiency of $\mathrm{Cu}$ in the UF-GP columns increased by less than 4\%. The other removal improvements were higher. The addition of external carbon source (as glucose) was also reported to enhance the metal removal efficiency in subsurface flow microcosms by Lesage et al. [31].

One of the drawbacks of using external carbon sources is that it increases the COD of the wastewater. This issue, however, must not be considered without comparing the effect of external and internal carbon sourced as a cause for residual COD in the effluent. The advantage of using external carbon sources is that CWs amended with these materials are less prone to clogging then wetlands with internal carbon source such as peat [32]. Additional aspect that should be addressed is the release of reduced sulfur species from the system. They are more toxic to the environment than sulfate and may cause odor nuisance in some cases. The influent and effluent COD and concentrations and the corresponding removal are shown in Tab. 9. Also the ratio $\mathrm{COD} / \mathrm{SO}_{4}^{2-}$ in the influent is given as it is an essential parameter for the bacterial sulfate reduction.

Table 9 COD and sulfates removal in the experimental system in weeks 44-49

\begin{tabular}{|c|c|c|c|c|c|}
\hline & \multicolumn{2}{|l|}{ COD } & \multicolumn{2}{|l|}{$\mathrm{SO}_{4}^{2-}$} & \multirow{2}{*}{$\begin{array}{l}\text { Influent } \\
\mathrm{COD} / \mathrm{SO}_{4}^{2-} \\
\text { ratio }\end{array}$} \\
\hline & $\begin{array}{l}\text { Concentration }^{1} \\
{\left[\mathrm{mg} \mathrm{O}_{2} / \mathrm{L}\right]}\end{array}$ & $\begin{array}{l}\text { Removal }^{2} \\
{[\%]}\end{array}$ & $\begin{array}{l}\text { Concentration }^{1} \\
{[\mathrm{mg} / \mathrm{L}]}\end{array}$ & $\begin{array}{l}\text { Removal }^{2} \\
{[\%]}\end{array}$ & \\
\hline Influent & $32 \pm 2$ & & $860 \pm 47.5$ & & 0.04 \\
\hline Effluent from: & & & & & \\
\hline UF-PP & $94 \pm 6$ & -197.0 & $742.5 \pm 36.25$ & 13.7 & \\
\hline $\begin{array}{l}\text { Influent+ECS } \\
\text { Effluent from: }\end{array}$ & $273 \pm 21$ & & $855 \pm 40$ & & 0.32 \\
\hline UF-GP & $69 \pm 11$ & 74.6 & $775 \pm 70$ & 9.4 & \\
\hline
\end{tabular}


The results in Tab. 9 show that, even though, COD of the wastewater with the external carbon source was about 9-fold higher than the influent COD of the wastewater without the external carbon source the effluent COD of the former wastewater is lower than for the latter. Also the effluent concentrations of sulfates in all the types of columns are comparable. Taking into account the influent and effluent concentration of sulfates it can be assumed that there is a possibility that reduced species may appear in the effluent in comparable amounts from the columns with the internal and external carbon source. It should also be mentioned that some of the reduced sulfur species were probably oxidized to elemental sulfur in the outflow zone of the columns or were volatilized. The $\mathrm{COD} / \mathrm{SO}_{4}^{2-}$ ratio in the influent with the external carbon source was 0.32 , this is, near the intended value of 0.3 , which was proved optimum for the bacterial sulfate reduction as reported by Song et al. [19]. This ratio was much lower for the influent without the external carbon source, namely 0.04 , however, the reduction of sulfates occurred as the organic-carbon source was in the media, so the actual ratio is unknown.

Noteworthy, no steady state was reached for the removal of metals after the addition of the external carbon source as it was indicated in Fig. 3e-h. This suggests that the treatment efficiency was still increasing making the external carbon source a reasonable alternative to the internal carbon source used in the experiment.

\section{Conclusions}

This study furnished new information and expanded the existing knowledge on industrial wastewater treatment in constructed wetlands. In fact, this is, to the best knowledge, the first publication studying the removal of metals and cyanide from electroplating wastewater in subsurface flow constructed wetlands. The aim of this study was to study the polishing of the electroplating wastewater pretreated using physical-chemical methods. High removal efficiency was achieved for all the metals of concern: $\mathrm{Cu}, \mathrm{Ni}, \mathrm{Zn}$, save $\mathrm{Pb}$, depending on the influent quality and the operation mode of a $\mathrm{CW}$. Also the removal of cyanides was invariably above $90 \%$ in all the types of columns. Higher influent concentrations of $\mathrm{Cu}, \mathrm{Ni}$ and $\mathrm{Zn}$ resulted in higher removal efficiency. The removal of $\mathrm{Pb}$ was decreased by elevated concentrations of other metals in the effluent. Higher HLR allowed for higher removal efficiency of metals in the UF columns. The role of plants in the removal of metals and cyanide was minor. Moreover, the observed effect of the presence of vegetation on the treatment efficiency was different for the metallic contaminants, thus it is difficult to draw 
definite conclusion. Application of peat as internal carbon source proved to affect significantly only the removal of $\mathrm{Ni}$ and $\mathrm{Zn}$, causing increased removal efficiency as compared to gravel substrate. The removal of metals and sulfate was increased when lactate as an external carbon source was added to the influent to stimulate the activity of SRB. The use of lactate allows achieving higher treatment efficiency than in the counterpart constructed wetlands with the internal carbon source and comparable effluent concentration of organic matter in the effluent.

\section{Acknowledgements}

The project was supported by Grant N N523 561938 from the Polish Ministry of Science and Higher Education. The lead author was granted scholarship in the Project "SWIFT (Scholarships Supporting Innovative Forum of Technologies)" POKL.08.02.01-24-005/10 cofinanced by the European Union under the European Social Fund.

\section{References}

[1] B. Bartkiewicz, Oczyszczanie ścieków przemysłowych (Industrial wastewater treatment), Wydawnictwo Naukowe PWN, Warszawa, Poland, 2006. [in Polish]

[2] K.D. Torrens, Activated sludge and cyanide: a deadly combination, Pollut. Eng. 32 (3) (2000) 23-24.

[3] J.K. Kiptoo, J.C. Ngila, G.M. Sawula, Speciation studies of nickel and chromium in wastewater from an electroplating plant, Talanta 64 (2004) 54-59.

[4] I.D.S. Henriques, R.T. Kelly 2nd, J.L.Dauphinais, N.G. Love, Activated sludge inhibition by chemical stressors-a comprehensive study, Water Environ. Res. 79 (2007) 940-951.

[5] K.B. Chipasa, Accumulation and fate of selected heavy metals in a biological wastewater treatment system, Waste Manag. 23 (2003) 135-143.

[6] E. Ranieri, T.M Young, Clogging influence on metals migration and removal in subsurface flow constructed wetlands, J Contam Hydrol 129-130 (2012) 38-45.

[7] B.G. Yeoh, Use of water hyacinth in wastewater treatment. Terminal Report, Standard and Industrial Res. Inst. of Malaysia, 1983. 
[8] S.A. Abbasi, Aquatic plants based water treatment systems in Asia, in: Aquatic Plants for Water Treatment and Resource Recovery, K.R. Reddy and W.H. Smith, eds., Magnolia Publishing, Orlando, Florida, 1987, pp. 175-198.

[9] J. Vymazal, L. Kröpfelová, Wastewater Treatment in Constructed Wetlands with Horizontal Sub-surface Flow, Springer, 2008.

[10] K.C. Shroff, Reuse of water and sludge for cultivation of variety of value added botanical species, in: ENPC-IIT Joint Workshop on Strategy and Technology for Water Quality Management, Indian Institute of Technology, Bombay, 1982, pp. 379-425.

[11] D.B. Kosolapov, P. Kuschk, M.B. Vainshtein, A.V. Vatsourina, A. Wiessner, M. Kaestner, R.A. Mueller, Microbial processes of heavy metal removal from carbon-deficient effluents in constructed wetlands, Eng. Life. Sci. 4 (2004) 403-411.

[12] J.F. Blais, Z. Djedidi, R.B. Cheikh, R.D. Tyagi, G. Mercier, Metals Precipitation from Effluents: Review, Pract. Period. Hazard. Toxic Radioact.Waste Manag. 12 (2008) 135-149.

[13] S.D. Wallace, R.L. Knight, Small-Scale Constructed Wetland Treatment Systems: Feasibility, Design Criteria, and O\&M Requirements. Water Environment Research Foundation, 2006.

[14] P.L. Younger, S.A. Banwart, R. Hedin, Mine Water: Hydrology, Pollution, Remediation. Kluwer Academic Publishers: London, United Kingdom, 2002.

[15] PIRAMID Consortium, Engineering guidelines for the passive remediation of acidic and/or metalliferrous mine drainage and similar wastewaters, European Commission 5th Framework RTD Project no. EVK-CT-1999-000021 "Passive In-situ Remediation of Acidic Mine / Industrial Drainage" (PIRAMID), University of Newcastle Upon Tyne: Newcastle Upon Tyne, United Kingdom, 2003.

[16] K.R. Reddy, R. DeLaune, Biogeochemistry of Wetlands: Science and Applications, CRC Press: Boca Raton, Florida, 2008.

[17] N. Fonder, T. Headley, Systematic Classification, Nomenclature and Reporting for Constructed Treatment Wetlands, in: Vymazal, J. (Ed.), Water and Nutrient Management in Natural and Constructed Wetlands. Springer Netherlands, 2011, pp. 191-219. 
[18] R.R. Dash, A. Gaur, C. Balomajumder, Cyanide in industrial wastewaters and its removal: A review on biotreatment, J. Hazard. Mat., 163 (2009) 1-11.

[19] Y.C. Song, B.C. Piak, H.S. Shin, S.J. La, Influence of electron donor and toxic materials on the activity of sulfate reducing bacteria for the treatment of electroplating wastewater, Water Sci. Technol. 38 (1998) 187-194.

[20] ISO 6060:1989 Water quality -- Determination of the chemical oxygen demand

[21] StatSoft, Inc., STATISTICA (data analysis software system), version 10. www.statsoft.com., 2011.

[22] H. Brix, Do macrophytes play a role in constructed treatment wetlands?, Water Sci.and Technol. 35 (5) (1997) 11-17.

[23] L. Marchand, M. Mench, D.L. Jacob, M.L. Otte, Metal and metalloid removal in constructed wetlands, with emphasis on the importance of plants and standardized measurements: A review, Environ. Pollut. 158 (2010) 3477-3461.

[24] A.K. Yadav, N. Kumar, T.R. Sreekrishnan, S. Satya, N.R. Bishnoi, Removal of chromium and nickel from aqueous solution in constructed wetland: Mass balance, adsorption-desorption and FTIR study, Chem. Eng. J. 160 (2010) 122-128.

[25] Y. Song, M. Fitch, J. Burken, L. Nass, S. Chilukiri, N. Gale, C. Ross, Lead and zinc removal by laboratory-scale constructed wetlands, Water Environ Res 73 (2001) 37-44.

[26] C.M. Neculita, G.J. Zagury, B. Bussière, Effectiveness of sulfate-reducing passive bioreactors for treating highly contaminated acid mine drainage: I. Effect of hydraulic retention time, Appl. Geoch. 23 (2008) 3442-3451.

[27] P. Gikas, E. Ranieri, G. Tchobanoglous, Removal of Iron, Chromium and Lead from Waste Water by Horizontal Subsurface Flow Constructed Wetlands, J. Chem. Technol. Biotechnol. 88 (2013) 1906-1912.

[28] A.K. Yadav, R. Abbassi, N. Kumar, S. Satya, T.R.Sreekrishnan, B.K. Mishra, The removal of heavy metals in wetland microcosms: Effects of bed depth, plant species, and metal mobility, Chem. Eng. J. 211-212 (2012) 501-507. 
[29] M. Scholz, J. Xu, H.I. Dodson, Comparison of filter media, plant communities and microbiology within constructed wetlands treating wastewater containing heavy metals, J. Chem. Technol. Biotechnol. 76 (2001) 827-835.

[30] C.M. Neculita, G.J. Zagury, B. Bussière, Passive treatment of acid mine drainage in bioreactors using sulfate-reducing bacteria - critical review and research needs, J.of Environ. Qual. 36 (2007) 1-16.

[31] E. Lesage, D.P. Rousseau, A.Van de Moortel, F.M. Tack, N. De Pauw, M.G. Verloo, Effects of sorption, sulphate reduction, and Phragmites australis on the removal of heavy metals in subsurface flow constructed wetland microcosms, Water Sci. Technol. 56 (2007) 193-8.

[32] P. Kennedy, P.J. van Geel, Hydraulics of Peat Filters Treating Septic Tank Effluent, Transport Porous Med. 41 (2000) 47-60. 